\title{
Market Structure and Optimal Payout Policy
}

\author{
Robert Beach ${ }^{1}$ \\ ${ }^{1}$ Department of Economics and Finance, East Tennessee State University, USA \\ Correspondence: Robert Beach, Department of Economics and Finance, East Tennessee State University, \\ Johnson City, TN 37614, USA. Tel: 1-423-439-7066
}

Received: January 14, 2022

Accepted: February 11, 2022

Online Published: February 20, 2022

doi:10.5539/ijef.v14n3p76

URL: https://doi.org/10.5539/ijef.v14n3p76

\begin{abstract}
This paper considers the relationship between market structure and payout policy within the context of an oligopoly in which firms must consider the strategic responses of their competitors. A differential game approach with a finite planning horizon is used for the analysis and a Markovian Nash equilibrium is obtained using a numerical method. The results suggest that given optimal payout policy market competition in the form of a duopoly results in greater reinvestment and earnings than that of a monopoly.
\end{abstract}

Keywords: capital structure, differential game, research and development, numerical methods, firm value, intertemporal choice

JEL: C7 - Game Theory and Bargaining Theory; D9 - Intertemporal Choice and Growth; G32 - Financing Policy, Financial Risk and Risk Management; Capital Ownership Structure, Value of Firms, Goodwill; O32 Management of Technological Innovation and R\&D; L1 - Market Strategy, firm Strategy, and Market Performance.

\section{Introduction}

A basic issue in corporate finance is how much of a firm's financial resources should be retained and reinvested in future growth and how much should be returned to share holders in the form of dividends or stock repurchases. Among the issues related to this are the irrelevance of payout policy (see Mogdigliani \& Miller, 1961); signaling and asymmetric information (Myers \& Maijlof, 1984); agency costs (Jenson \& Meckling, 1976); tax issues having to do with capital gains and stepped up basis (Modigliani \& Miller, 1963); and the impact of risk aversion with respect to unanticipated market shocks in the future (Galai \& Masulis, 1976).

This paper, consistent with DeAngelo and DeAngelo (2004) and others, assumes there is an optimal payout policy. The model is based on the concept of a residual dividend policy that says dividends are paid out after providing for the optimal reinvestment of capital. Similar to the Gordon Growth model firm value is based on the present value of dividends paid out over the life of the firm. This is considered within an oligopoly in which firms with similar technologies and products compete.

A differential game approach is used to consider the dynamics of the model. The differential game is represented in continuous time over a finite time period. For each firm the model solves for the optimal payout policy, capital policy, equity, and debt. These are all represented as intertemporal functions over a N-period planning horizon. For differential games there is limited class of models for which analytical solutions can be obtained. For this reason a numerical method is used for the analysis. For tractability an oligopoly made up of two firms is considered. The final step in the analysis is a numerical solution to the basic model.

This paper contributes to the literature in three ways. First, it contributes to the optimal payout policy literature by presenting a context in which payout policy is determined by strategic considerations over a finite planning horizon. In this framework the optimal payout policy can vary as market conditions change over the planning horizon. Second, it contributes to the literature on oligopolies and duopolies by suggesting a solution method to obtain a Markovian Nash equilibrium for differential games similar to the one here. Third, it asks the question which type of market structure, monopoly or duopoly, provides for more economic growth and earnings.

\section{Related Literature}

The issues related to payout policy cover a broad range of topics having to do with maximizing firm value, corporate governance and agency, tax policy, reinvestment for future growth, and whether dividends or 
repurchases is the preferred method of payout. This literature discussion first takes a look across all of these issues and then discusses in detail the literature related to the issues discussed in this paper. Specifically which market structure results in higher economic growth. The central issue is how much of earnings should be reinvested in the growth of the company and how much should be paid out in some form to shareholders over the planning horizon of the firm. In the process optimal reinvestment and capital structure are also determined. A unique feature of the approach here is these issues are considered in the context of an oligopoly in which the firms use similar technologies and produce similar products with little product differentiation. Thus the decisions of other firms have to be considered in the decision making process.

The modern discussion of payout policy usually starts with John Lintner's 1956 paper in which he concluded that dividend payouts were sticky since firms tended to only increase dividends if they were sustainable and were reluctant to lower dividends since that would be taken as a negative sign by investors. Shortly after Modigliani and Miller (1961), under a number of restrictive assumptions (no taxes or uncertainty to name two) concluded payout policy has no effect on firm value.

Many papers have dealt with the signaling or asymmetric information model developed by Bhattacharya (1979) and others. Signaling theory proposes that change in future profitability can be deduced by changes in the current payout policy. Empirical studies have been inconclusive. A number of studies have a positive relationship between dividend increase and future profitability. See for example Nissin and Ziv (2001). On the other hand Benartz, Michaely, and Thaler (1997), among others, find no relationship between dividend increases and future profitability.

Others have argued that agency costs drive dividend policy. Agency costs refer to the notion that if too much cash is held by the firm company insiders are more likely to spend cash on more speculative investments that are not in the long run interest of the firm. See for example Jensen (1986). Empirical evidence is mixed. Agrawal and Jayaramaa (1994) supports the model while Lie (2000) finds no evidence.

Another determinant of dividend policy has to do with tax policy and the clientele effects. That is, investors invest in firms that have a dividend policy that they favor. Studies that support this theory are Kalay and Michaely (1993) and Litzenberger and Ramaswamy (1979); whereas Black and Sholes (1974) find no evidence to support agency theory.

One of the criticisms of the Modigliani and Miller framework is that it makes an all or nothing assumption. That is, all of free cash flow is paid out to share holders or nothing is paid out. This is the source of the irrelevance. However, if the model allows for a partial payout, then not only does the type of payout matter, but now optimality includes the decision to set aside cash flow for the future growth and profitability of the firm. DeAngelo and DeAngelo (2004) consider what happens if not all cash flow is paid out in the form of dividends or repurchases. They argue that in this case one of the motives for not paying out all free cash flow is to mitigate future market risks and uncertainty with respect to free cash flow. Lee, Gupta, Chen, and Lee (2011) propose a formal model based on this uncertainty. Their analytical results suggest that there is an optimal payout ratio and derive optimal results given changes in total risk and asymmetric risk.

There are a handful of papers that consider payout theory within the context of competitive markets. That is, the payout decision takes into account similar decisions of other firms in the same market. Hoberg, Phillips, and Prubhala (2012) propose that a firm in a market fluidity from development of new products pays out less than other firms. Their empirical results support this. They use software that parses the text from the business descriptions of IPO firms or firms raising new venture capital to identify firms that are in highly fluid product markets. Massa, Rehman, and Vermaelon (2005) argue that a firm by repurchasing its share sends a positive signal about itself and a negative signal about its competitors. This triggers a "mimicking" response from the other firms in which all firms in the market increase their repurchases. They show that there is less benefit to using this strategy if the firm is in a market in which is more concentrated.

This paper considers optimal payout policy and its impact on capital structure, as well as market structure in a somewhat stylized manner. That is, no distinction is made as to whether the payout is in the form of dividends or repurchases. The results are based on two scenarios. First, the market is characterized as a monopoly; then second, as a duopoly.

\section{Differential Game Model}

The differential game developed in this paper is based on a market relationship in which there is a small number of firms producing similar products using similar technology. Each firm, given its technology and production efficiency, must decide what part of its earning should be put aside for future growth and increasing future 
profits and how much is to be paid out in the form of dividends or repurchases.

The assumption is that firm value, much like the Gordon growth model, equals the present value of shareholder dividends. The logic used is similar to that embodied in the residual dividend model. That is, the decision variable is the percent of earnings that should be retained and the remaining amount to be paid out as dividends, allowing for the fact that part of the target reinvestment will be financed by debt.

Aside from differences in technology and production efficiency, each firm has an initial endowment of equity, say from an IPO. Given the target equity funding out of earnings, the required debt issue is determined and hence the debt to equity ratio.

A Markovian Nash equilibrium occurs when none of the firms in the oligopoly have an incentive to change its strategy. The strategies are Markovian since they are time dependent and respond to the intertemporal decisions of the other player,

The argument for a finite planning horizon is twofold. First, a typical exit strategy for investors in small cap, high growth firms is to grow the company and then get acquired by or merge with a larger firm. Usually the investors come in the form of a venture capital fund or some other form of private equity. These funds typically focus on one or two firms and have a life of five to ten years. Second, the numerical method employed here discretizes the decision space and uses a type of "shooting" algorithm to converge to the decision functions that maximize firm value and achieve the target capital over the planning horizon. A fixed planning horizon facilitates this method and allows for convergence to a Nash equilibrium in which neither firm has an incentive to change its strategy.

Each firm in the oligopoly maximizes the following:

$$
J^{n}=\int_{0}^{T} e^{-\omega t}\left\{P_{t} A K_{t}^{\alpha}-\theta R_{t}^{\gamma}-r(1-\theta) R_{t}\right\} d t
$$

where $J^{n}$ is the value of the firm; $\omega$ is the weighted average cost of capital (WACC) and is the firm's discount rate; $K_{t}$ represents capital assets devoted to production at time $t ; A$ is a scale coefficient and $\alpha$ is the exponent for the production function which represents the value of the firm's net output; $R_{t}$ is the firm's reinvestment in R\&D projects; $\theta$ represents that portion of reinvestment that is meet by equity, and $r$ is the cost of acquiring debt.

To simplify the model, the market price for the firm's product is determined by a downward sloping price function:

$$
g-h K_{t} \text {. }
$$

This is meant to capture the effect of an increase in supply on the market price. The capital assets here refer specifically to those assets used in the production of output. Any other capital created from net earnings is assumed to be available to shareholders at some future point in time.

The state variable for the system given by Equations 1 and 2 defines the instantaneous growth of capital for each firm in the oligopoly (Note 1). That is:

with the conditions:

$$
\dot{K}_{t}=\theta R_{t}^{\gamma}
$$

$$
\begin{gathered}
K_{0}=\text { initial capital } \\
P_{t}=g-h \sum_{n=1}^{N} K_{t}^{n}=\text { price at time } t
\end{gathered}
$$

where $K_{0}$ represents the initial equity of the firm from, say, an IPO and $P_{t}$ represents the market price at time $t$.

Equation 3 states that capital increases as a target amount of earnings is retained for future investment.

The Hamiltonian equation and the first order conditions based on Pontryagin's maximum principle for the typical firm for the system represented by Equations 1 through 4 are stated in Equations 5 through 7 below.

$$
\begin{aligned}
& H^{n}=\left\{P_{t} A K_{t}^{\alpha}-\theta R_{t}-r(1-\theta) R_{t}\right\}+\lambda_{t} \theta R_{t}^{\gamma} \\
& \frac{\partial H^{n}}{\partial R_{t}}=-\theta \gamma R_{t}^{\gamma-1}-r(1-\theta)+\lambda_{t} \theta \gamma R_{t}^{\gamma-1}=0 \\
& \frac{\partial H^{n}}{\partial K_{t}}=P_{t} A \alpha K_{t}^{\alpha-1}-h A K_{t}^{\alpha}=\omega \lambda_{t}-\dot{\lambda}_{t}
\end{aligned}
$$

where $\lambda_{t}$ is the costate variable and all other variables are defined above.

\section{Simulation Results}

Given that for differential games there is limited class of models for which analytical solutions can be obtained, a 
numerical solution to the continuous model is derived. Recall the initial level of capital, $K_{0}$, is equal to the equity raised from, say, an IPO. Given this initial level of capital, the firm chooses its level of reinvestment in capital to maximize the present value of earnings, the firm's value. The assumption is that new reinvestment is funded partly from earnings and partly from new debt. The actual new capital created is based on a function that determines the rate at which the reinvestment is converted into capital. To put it simply the firm maximizes earnings over time taking into account the creation of new capital less interest paid on the debt funded portion.

The scenario is a monopoly in which there is no competing firm compared to a duopoly in which two similar firms subject to the same constraints compete. The numerical solution is based on a discretized version of the equations in Section 3. The solution method used here is a type of discrete "shooting" method in which successive guesses of the initial costate variable are made until the maximum firm value is determined. Changes in the initial costate variable are used to determine the level of reinvestment that maximizes firm value. In the case of a monopoly this results in the solution.

In the case of a duopoly a final solution is subject to the solution of the other firm. A Nash equilibrium is obtained when the intertemporal prices for each solution are consistent. The step by step algorithm is given in Appendix A.

The parameterization of the model defines a typical growth case. The initial issue of equity from the IPO is set to $\$ 1000$ for the duopoly firms and $\$ 2000$ for the monopoly. (Although arbitrary, all dollar amounts are expressed in thousands of dollars.) The planning horizon is set to fifteen years. This scenario is roughly similar to a firm emerging from the startup stage and entering a rapid growth stage. Often this is financed by a private equity or venture capital fund with a merger or acquisition exit strategy in mind.

The key parameters are the weighted average cost of capital, the discount rate, set for the monopoly and duopolies at $12 \%$ and the cost of debt, the interest rate, set at $8 \%$. Table 1 summarizes the key parameters.

Table 1. Parameter values

\begin{tabular}{cll}
\hline Parameter & Value & Description \\
\hline$A$ & 2.0 & Scaling factor for R\&D production \\
$\alpha$ & 0.6 & Exponent for production fuction \\
$r$ & $10 \%$ & Interest on debt \\
$K_{0}$ & 1000 & Initial equity from an IPO \\
$T$ & 15 & Planning horizon (years) \\
$\theta$ & 0.4 & Percent of equity for reinvestment \\
$\rho$ & $12.0 \%$ & WACC \\
\hline
\end{tabular}

Monopoly versus Duopoly. In this case we compare earnings, reinvestment, dividends, capital formation, and debt in a monopoly and a duopoly consisting of two similar firms. Charts 1 through 5 capture these results. Here, Earnings reinvestment, dividends, capital formation, and debt are compared for a monopoly, a duopoly and the market values when the two duopoly firms are summed to form the duopoly market.

From the Earnings chart, Figure 1, the monopoly is considerably higher over time than that of an individual duopoly firm. However, when the total of the two duopoly firms is considered total earnings for the duopoly is greater and grows over time.

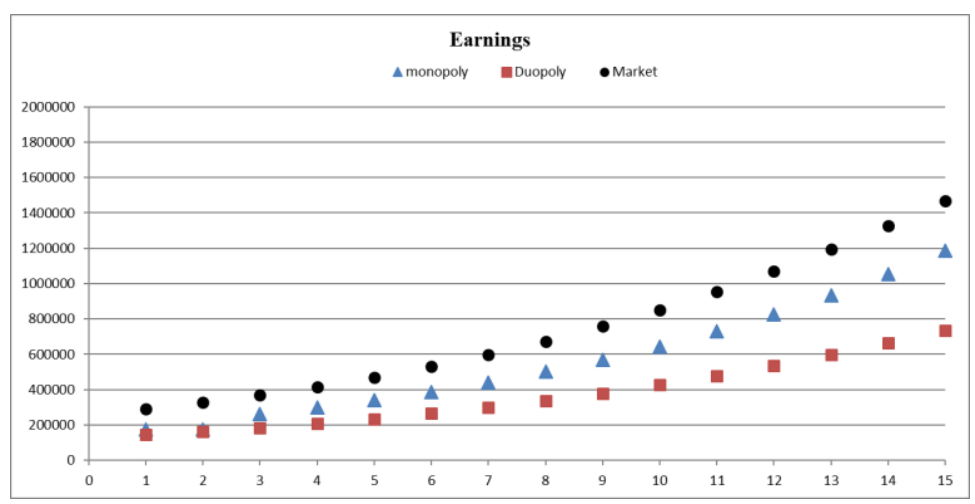

Figure 1. Earnings 
In Figure 2, reinvestment for the monopoly is considerably more than that of an individual duopoly, but the duopoly total is very similar. But in Figure 3 we see that individual duopolies actually pay out more in dividends so that the duopoly market actually pays out considerably more in dividends than the monopoly.

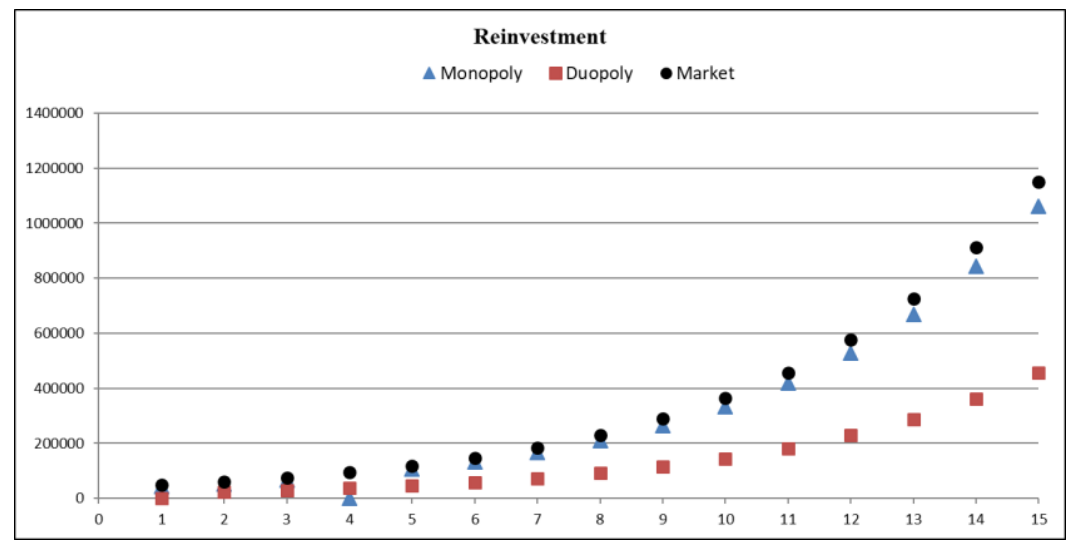

Figure 2. Reinvestment

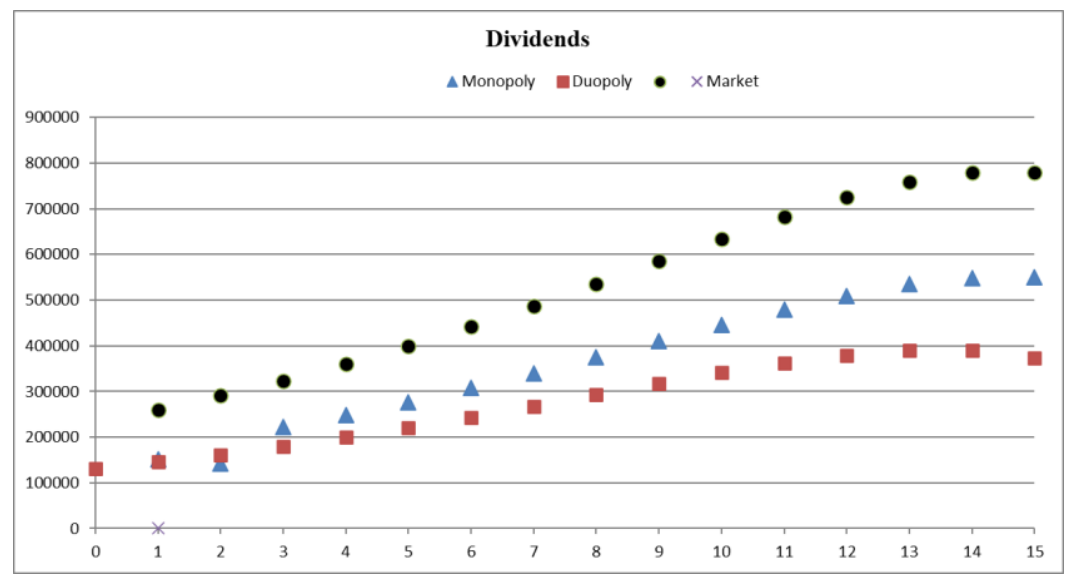

Figure 3. Dividends

In Figure 4 we see that capital formation over time for the monopoly grows more than for the individual duopoly, but when you take into account the total capital for the duopoly market it is significantly greater. This is also facilitated by the fact that although the monopoly takes on significantly more debt to fund its reinvestment than an individual duopoly, the total debt for the duopoly market is significantly more than that of the monopoly, as in Figure 5 .

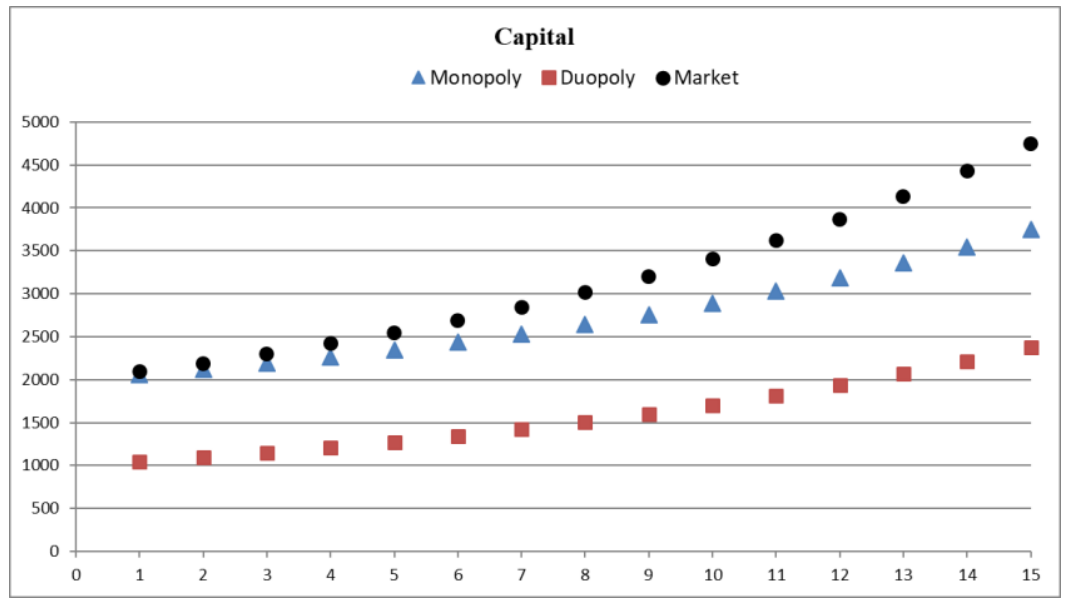

Figure 4. Capital 
In summary, because of the greater capital formation in the duopoly, funded by greater market debt, share holder rewards in the form of dividends, and hence firm value, is greater for the duopoly. Also because of the greater level of debt, bond holders are rewarded more in the form of interest and coupon payments.

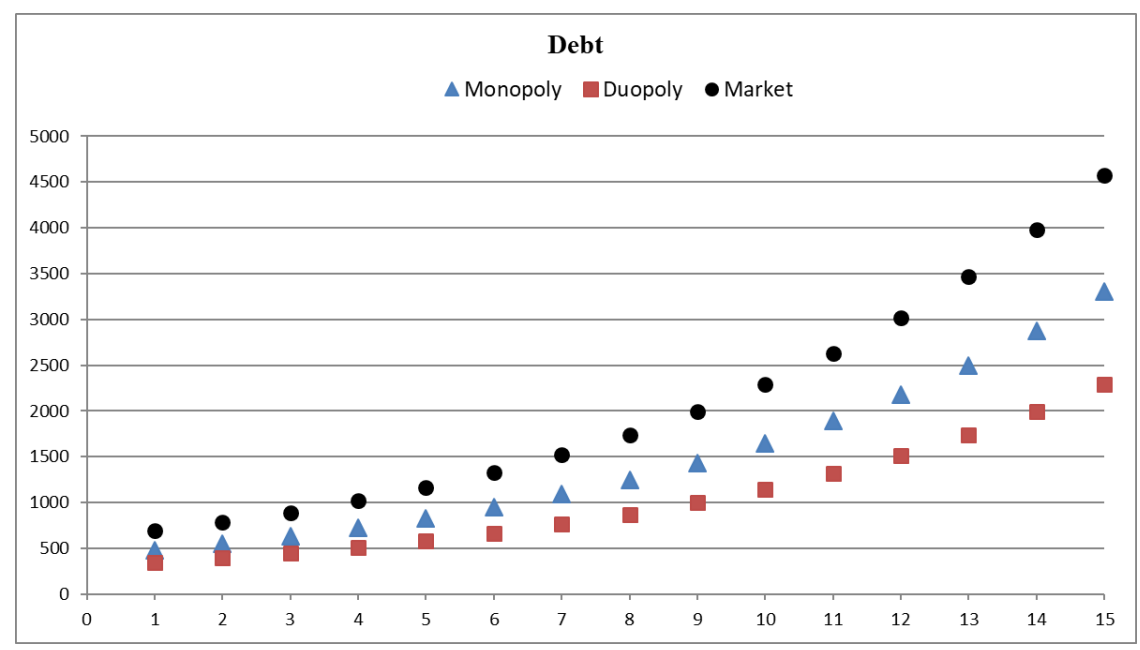

Figure 5. Debt

\section{Conclusion}

The argument for competitive markets, here represented by a duopoly versus a monopoly, is typically based on the lower market prices that result and the additional social utility that accrues from this. Here, we focus on the additional earnings and the dividends that get paid out to shareholders, as well as the additional interest that gets paid to debtholders.

In summary, what emerges is a scenario where because the duopoly market collectively generates higher earnings, dividends, and capital than the monopoly market, we can conclude that the economy is better off when there is some level of competition.

\section{Acknowledgements}

The author expresses gratitude to the faculty of the Economics and Finance Department at East Tennessee State University, Johnson City, Tennessee, United States, for seminar discussions that gave shape and direction to this research.

\section{References}

Agrawal, A., \& Jayaramen, N. (1994). The dividend policies of all-equity firms: A real test of the free cash flow theory. Managerial Decision Economics, 15, 139-148. https://doi.org/10.1002/mde.4090150206

Benartz, S., Roni, M., \& Richard, T. (1997). Do changes in dividend payouts signal the future or the past. Journal of Finance, 52(3), 1007-1043. https://doi.org/10.1111/j.1540-6261.1997.tb02723.x

Bhattacharya, S. (1979). Imperfect information, dividend policy, and the Bird in the Hand Fallacy. Bell Journal of Economics, 10(1). https://doi.org/10.2307/3003330

Black, F., \& Scholes, M. (1974). The effect of dividend prices on common stock prices and returns. Journal of Financial Economics, 2, 1-22. https://doi.org/10.1016/0304-405X(74)90006-3

Cheng-dow, L., Manak, G., Hong, Y. C., \& Alice, L. (2011). Optimal payout ratio under uncertainty and the flexibility hypothesis: Theory and empirical evidence. Journal of Corporate Finance, 17(3). https://doi.org/10.1016/j.jcorpfin.2011.02.004

DeAngelo, H., \& Linda, D. (2000). Payout Policy irrelevance and the valuation puzzle.

Galai, D., \& Masulis, R. W. (1976). The option pricing model and the risk factor of stock. Journal of Financial Economics, 3, 53-81. https://doi.org/10.1016/0304-405X(76)90020-9

Hoberg, G., Gordan, P., \& Nagpurand, P. (2012). Product market threats, payouts and financial flexibility. Journal of Finance, 69(1). https://doi.org/10.2139/ssrn.1787315 
Jensen, M. (1986). Agency costs of free-cash flow, corporate finance, and takeovers. American Economic Review, 76, 323-329.

Jensen, M., \& Meckling, W. (1976). Theory of the firm: Managerial behavior, agency costs, and ownership structure. Journal of Financial Economics, 3, 305-360. https://doi.org/10.1016/0304-405X(76)90026-X

Kalay, A., \& Roni, M. (1993). Dividends and Taxes, a re-examination. Financial Management, 29(2), 55-75. https://doi.org/10.2307/3666285

Litzenberger, R. H., \& Krishna, R. (1979). The effect of personal taxes and dividends on capital asset prices: Theory and empirical evidence. Journal of Financial Economics. https://doi.org/10.1016/0304-405X(79)90012-6

Massa, M., Zahid, R., \& Theo, V. (2005). Mimicking repurchases. https://doi.org/10.2139/ssrn.674501

Modigliani, F., \& Miller, M. H. (1958). The cost of capital, corporation finance, and the theory of investment. American Economic Review, 48, 261-297.

Modigliani, F., \& Miller, M. H. (1963). Corporate income taxes and the cost of capital: A correction. American Economic Review, 53, 433-443.

Myers, S. (1984). The capital structure puzzle. Journal of Finance, 39, 575-592. https://doi.org/10.2307/2327916

Myers, S., \& Majluf, N. S. (1984). Corporate financing and investment decisions when firms have information that investors do not have. Journal of Financial Economics, 13, 187-221. https://doi.org/10.1016/0304-405X(84)90023-0

Nissan, D., \& Amir, Z. (2001). Dividend changes and Future Profitability. Journal of Finance, 56(6), 2117-2133. https://doi.org/10.1111/0022-1082.00400

Note

Note 1. The model is continuous, the term instantaneous refers to a point on a curve. Here it is the change in $\mathrm{R} \& \mathrm{D}$ capital at a point along the R\&D capital curve. As another example, below there is a reference to net earnings. The sum of instantaneous net earnings over the planning horizon, its integral, equals retained earnings.

\section{Appendix A: Numerical Solution Algorithm}

The steps for the numerical solution are:

1) Discretize the space for the decision variable, $R_{t}$. Here there are 15 years.

2) From the Hamiltonian conditions the discretized equations for the costate $\left(\lambda_{t}\right)$; decision variables $\left(R_{t}\right)$; and the state variable, $K_{t}$, are derived:

$$
\begin{aligned}
& \lambda_{t+1}=(1+\omega) \lambda_{t}-P_{t} A \alpha K_{t}^{\alpha-1} \\
& K_{t+1}=K_{t}+R_{t}^{\gamma} \\
& R_{t}=\left(\frac{\gamma\left(\lambda_{t}-r\right)}{r(1-\theta}\right)^{1 /(\gamma-1)} \\
& P_{t}=g-\sum_{n=1}^{N} K_{t}^{n} \\
& \text { Earning }_{t}=P_{t} A K_{t}^{\alpha}-r(1-\theta) R_{t}^{\gamma} \\
& \text { Dividend }_{t}=\text { Earning }_{t}-r(1-\theta) R_{t}^{\gamma}
\end{aligned}
$$

3) Set the initial value of capital, $K_{t}$.

4) Set initial guess for $\lambda_{t}$ over the discretized space.

5) Given the initial guess for the costate variable and initial capital: Calculate $R_{t}$ from A3.

6) Calculate $P_{t}$ from A4.

7) Calculate Earnings $s_{t}$ and Dividends $s_{t}$ from A5 and A6.

8) Calculate $K_{t+1}$ and $\lambda_{t+1}$ from A1 and A2; loop through again by going to Step 5. Continue looping until N years. 
9) Firm value is the present value of earnings years through $\mathrm{N}$.

10) Using a half-table search process make another guess for $\lambda_{0}$ and proceed in this manner until the maximum firm value is obtained.

11) To get the Nash equilibrium for the duopoly, note that $P_{t}$ depends on $K_{t}$ for both firms and proceed in a similar manner until the $l$ to $N$ prices, $P_{t}$, are consistent for both firms.

\section{Copyrights}

Copyright for this article is retained by the author(s), with first publication rights granted to the journal.

This is an open-access article distributed under the terms and conditions of the Creative Commons Attribution license (http://creativecommons.org/licenses/by/4.0/). 